\title{
A TRADUÇÃO COMO EXERCÍCIO DE TEATRO ${ }^{1}$
}

por Renata M. Molinari ${ }^{2}$

Passaram-se mais de vinte anos da morte de Thierry Salmon. Neste arco de tempo, além da Homenagem de Bolonha que vem aqui reproduzida, do encontro dedicado ao seu teatro em ocasião da apresentação do Projet Thierry Salmon da Ècole des Maîtres em Liegi, em 2004, e da extraordinária mostra-instalação Traces, realizada entre a Bélgica e a Itália no ano de 2008, não houve muitas iniciativas dedicadas ao seu teatro e à sua experiência humana e artística. Difícil organizar testemunhos e núcleos temáticos em torno de um trabalho que refutava definições e rígidas categorias metodológicas: ainda assim era um trabalho rico de propostas pedagógicas cultivadas com método e exploração tenaz, férteis de propostas inovativas e internamente bem estruturadas em singulares percursos criativos. Exercícios de criação e composição, do trabalho sobre o personagem à invenção de estruturas dinâmicas para improvisar, constantemente, sempre mais impulsionado e atraído

1

* Tradução: Eduardo De Paula, Maurício Paroni de Castro; Colaboração: Renata Margherita Molinari. ** Publicação autorizada pela autora.

*** MOLINARI, Renata M. La traduzione come esercizio di teatro; texto escrito exclusivamente para a publicação brasileira (N.T.).

${ }^{2}$ Dramaturga, escritora e professora de dramaturgia. Acompanhou muitas fases do trabalho de Jerzy Grotowski e participou de modo contínuo do percurso artístico de Thierry Salmon assinando a dramaturgia dos seus principais projetos, desde "As Troianas" à "O assalto ao céu”. Foi coordenadora do Il Patalogo - Annuario dello Spetacolo (Milano: Ubulibri); é autora de vários livros, entre eles Diario dal Teatro delle Fonti. Polonia 1980 (Firenze: La casa Usher, 2006), Il lavoro del dramaturg nel teatro dei test con le ruote - dalla Germania all'aria italofrancese nella storia e in un percorso professionale (Milano: Ubulibri, 2007), Viaggio nel teatro di Thierry Salmon, Attraverso «I demoni» di Fëdor Dostoevskij (Milano: Ubulibri, 2008). No Brasil colaborou com a publicação do livro "O Teatro Laboratório de Jerzy Grotowski, 1959 - 1969” (Editora Perspectiva - SESC, 2007). Abriu a sua biblioteca pessoal ao público, fundando e coordenado o espaço La Bottega dello Sguardo Biblioteca Teatrale Molinari, voltado para os estudos das artes do espetáculo e laboratórios de escrita. 
pela "permeabilidade ao real" ... Uma mina de instrumentos e impulsos para aqueles que queiram interrogar-se sobre a vida no teatro e a complexidade das relações inseridas em um núcleo de criação artística.

Podemos procurar esses instrumentos e impulsos nos espetáculos de Salmon (de difícil documentação) e na experiência dos seus colaboradores e alunos. Cada um de nós é depositário de uma parte do trabalho de Thierry, de um núcleo de sentido no seu fazer teatral: um fazer que, além da memória e dos rastros de singulares testemunhos pessoais, cada um buscou desenvolver em percursos artísticos diversos, não necessariamente teatrais.

Um mestre indiscutível do século XX, Jerzy Grotowski, falava de "influências anônimas" a propósito da relação entre o seu trabalho e os jovens grupos que de tempos em tempos encontrava: eis que podemos procurar estas influências também para o trabalho de Thierry Salmon, com aproximações às surpreendentes transformações e - porque não? - também às traições que cada "influência anônima", transmitida através de simples relações pessoais, sem autenticação de escola ou etiquetas de sistema, pode portar consigo.

Certo é que, em cada uma das vezes que nestes anos alguém bateu à minha porta (e agora aquela da Bottega dello Sguardo), trazendo perguntas em torno da experiência artística e pedagógica de Thierry, colocou-se em ação um processo não apenas e nem tanto de recuperação de memórias e documentos, mas de reconstrução de um possível "outro modo" de estar em relação com o teatro, de criar - obras e relações - através do teatro.

Jovens que jamais encontraram diretamente Thierry e o seu fazer teatral, intuíram, entreviram (e continuam a fazê-lo!), através das histórias de testemunhas, das imagens colhidas também no caos da web, fotos pessoais compartilhadas em momentos de intimidades artísticas, o eco de palavras distantes que continuam a ressonar no presente, que a tudo isto diz respeito, diz respeito aos seus questionamentos presentes do teatro. Assim, cada pesquisa sobre o teatro de Thierry Rascunhos | Uberlândia, MG | v.6 | n.1 | p.35-38 | jan./jun.2019 | ISSN 2358-3703 
Salmon é também e sobretudo uma pesquisa sobre o teatro que queremos fazer, hoje, sobre a possibilidade da eficácia teatral no presente.

Assim os documentos se alternam às histórias, aos esquecimentos também, às lacunas de histórias ainda vivas: fotos de cenas ao lado de imagens da vida, de escuta, de silêncio. Tudo colabora para traçar possíveis vias entre o passado e o presente.

Esse processo parece ainda mais potencializado, parece invocar um escavo mais profundo, quando as perguntas vêm de lugares distantes, de uma outra tradição teatral, quando passam através de uma outra língua: é o caso da pesquisa, na Itália, de José Eduardo De Paula.

Sabemos, e a intrevista de Salmon aqui publicada ${ }^{3}$ confirma com força, o quão importante foi para ele "trabalhar no exterior", confrontar-se, em cena e fora dela, com outras línguas.

A tradução tornava-se, para ele, um tipo de treinamento para a representação, a tradução "em tempo real", em cena, entre dois atores que contam a mesma história, dizem a mesma coisa em duas línguas diversas, tornava-se emblema do acolhimento da diversidade em seu teatro, reforçava a representação na abertura à espectadores de diversas culturas, na declaração explicita do jogo cênico. Traduzir em tempo real, em cena, nega a ilusão e reforça a relação, tornando-a ativa, na permeabilidade ao real.

\footnotetext{
3 VERSTRAETEN, Fabienne. É preciso que o real penetre no espetáculo; na versão completa desta publicação : p.130.
} 
A tradução como exercício de teatro foi para mim uma das experiências mais fortes no trabalho sobre Dostoevskij: na Itália, na Bélgica, na Russia. Colocava o trabalho, a dificuldade do encontro, na raiz e ao centro da representação.

Esta particularidade do trabalho com Thiery foi despertada em mim nos meses de escuta e apoio da pesquisa de Eduardo De Paula: mais uma vez, a demanda revelava uma inesperada via na pesquisa, na reconstrução do percurso de trabalho de Thierry Salmon aqui levado em consideração.

Assim a tradução da Homenagem foi inserida completamente neste particular exercício de teatro, aprendido com Thierry. Depois de algumas tentativas de reorganizações sistemáticas de um material que no original mantinha o andamento da comunicação oral e o pathos - às vezes gaguejante, às vezes redundante - de palavras nunca pronunciadas ao mesmo tempo, no grupo dos colaboradores, decidimos deixar "as coisas como eram", também em suas desomogeneidades (como é engraçado ler meu nome às vezes como Renata, às vezes como Renata Margherita ...), não por preguiça, mas para deixar espaço ao leitor para entrar nos tempos teatrais e no espaço de jogo de uma tradução que lança novamente sobre o plano da representação as diversas possibilidades de uma história "verdadeira".

Dessa descoberta agradeço novamente a Thierry por este trabalho feito em conjunto, e agradeço ao Eduardo por me fazer redescobrí-lo. 